\section{CITAÇÃO}

Marques, S. \& Cotrim, F. (2019)

Grão de pólen de Hibiscus,

Rev. Ciência Elem., V7(03):074.

10.24927/rce2019.074

\section{EDITOR}

José Ferreira Gomes,

Universidade do Porto

\section{RECEBIDO EM}

16 de outubro de 2019

\section{ACEITE EM}

19 de outubro de 2019

\section{PUBLICADO EM}

17 de dezembro de 2019

\section{COPYRIGHT}

(C) Casa das Ciências 2019.

Este artigo é de acesso livre, distribuído sob licença Creative

Commons com a designação CC-BY-NC-SA 4.0, que permite a utilização e a partilha para fins não comerciais, desde que citado o autor e a fonte original do artigo.

\title{
Grão de pólen de Hibiscus
}

Em 1977, Charles e Ray Eames realizaram Powers of Ten, um filme encomendado pela IBM que adaptava o livro Cosmic View do holandês Kees Boeke, permitindo ao espectador fazer uma viagem vertical, com início no Central Park, sobre um eixo ascendente em direcção ao pó da galáctica a $10^{25}$ metros de distância e vertiginosamente descendente, revelando os fragmentos atómicos da realidade a $-10^{16}$ metros de profundidade.

Olhando para a relatividade da escala do Universo, percebemos que as coisas, porque são exponenciáveis, se tornam diferentes em diferentes escalas e que as imagens que delas se retiram, acontecem na variação dessa ordem de magnitude.

Muito depois dos delicados desenhos micrográficos de Robert Hooke, esta imagem atmosférica - que na legenda se desvenda como um grão de pólen de hibisco - move-se no antagonismo da sua imensidão mínima, quebrando os obstáculos da opacidade e mostrando as complexas formas da sua origem. Acima de tudo, revela o afastamento do peso e da gravidade que o infinitamente pequeno privilegia.
A fotografia do grão de pólen da flor de Hibiscus, foi tirada durante uma aula prática da disciplina de Biologia e Geologia e reflete o quão espetacular é o mundo microscópico e também como as aulas e a biologia, podem ser fascinantes para os alunos (e para os professores).

Contrariamente à opinião de muitos, o telemóvel faz parte do material das minhas aulas práticas e é recompensador ver os alunos a ficarem maravilhados com as fotografias que tiramos e que permitem apercebermo-nos, ainda mais, dos pormenores espetaculares das imagens dadas pelas lupas e pelos microscópios.

0 pólen, ao ser fotografado, deixou de ser apenas algo de que falo a propósito da reprodução sexuada ou do problema da extinção das abelhas, e passou a ser também aquela entidade misteriosa e espetacular de quem nos apropriámos e que nos fascina. É a arte da biologia!

\section{Fátima Cotrim}

Escola Secundária de Odivelas

rce.casadasciencias.org

Susana Marques

FBAUP/Universidade do Porto 


\section{REVISTA DE CIÊNCIA ELEMENTAR}

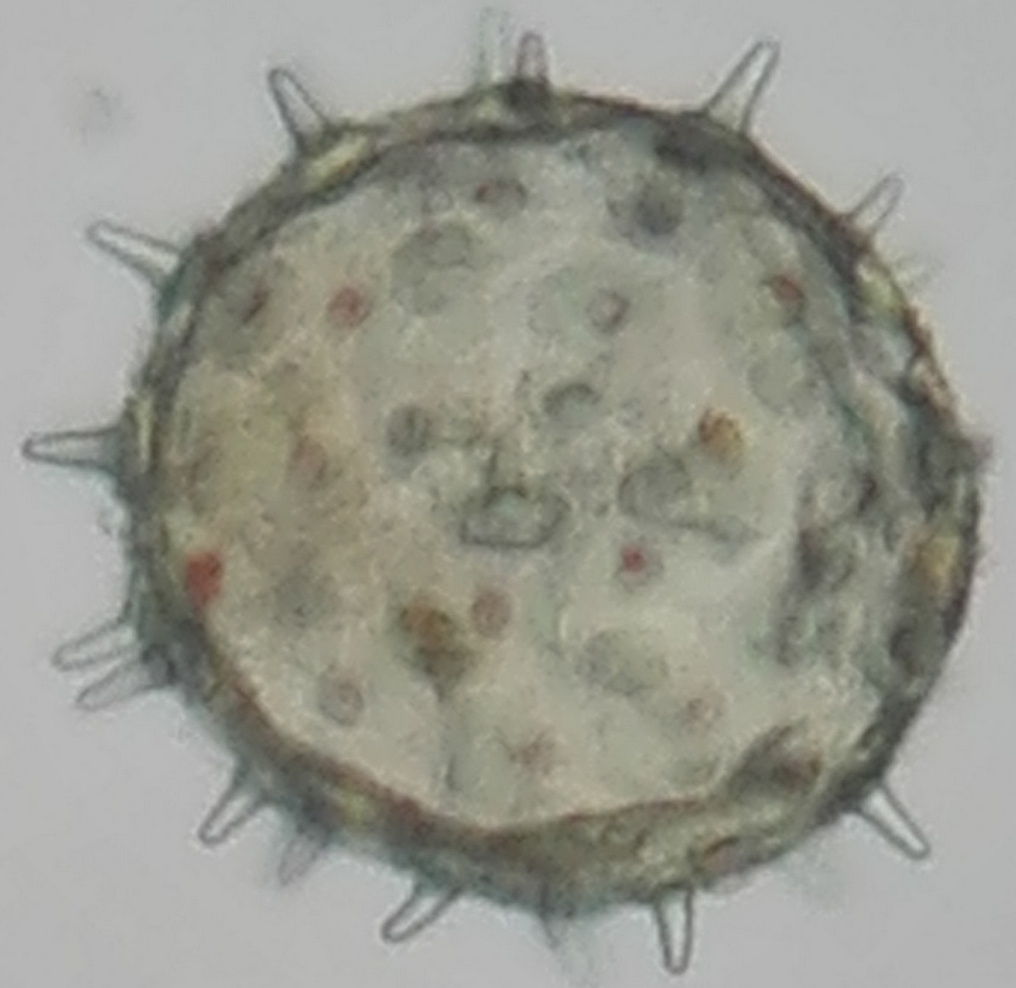

